\title{
The Effect of Chlorhexidine Varnish on Root Caries: A Systematic Review
}

\author{
D.E. Slot ${ }^{\mathrm{a}}$ N.C. Vaandrager ${ }^{\mathrm{b}}$ C. Van Loveren ${ }^{\mathrm{c}}$ W.H. Van Palenstein Helderman ${ }^{\mathrm{d}}$ \\ G.A. Van der Weijden ${ }^{\mathrm{a}}$ \\ ${ }^{a}$ Department of Periodontology, ${ }^{b}$ School of Dentistry, and ${ }^{c}$ Department of Cariology, Academic Centre for \\ Dentistry Amsterdam, University of Amsterdam and VU University Amsterdam, Amsterdam, and \\ ${ }^{\mathrm{d}}$ Department of Global Oral Health, Radboud University Nijmegen Medical Centre, Nijmegen, The Netherlands
}

\section{Key Words}

Chlorhexidine varnish $\cdot$ Decayed root surfaces $\cdot$ Root

caries $\cdot$ Root caries activity $\cdot$ Root caries incidence

\begin{abstract}
Objective: The aim of this study was to systematically review the present literature on the effect of chlorhexidine varnish (CHX-V) on root caries. Materials and Methods: The MEDLINE-PubMed, the Cochrane-CENTRAL and EMBASE databases were searched through December 2010 to identify any appropriate studies. Root caries incidence and root caries activity were selected as outcome variables. Results: An independent screening of the unique titles and abstracts of 24 MEDLINE-PubMed, 14 Cochrane-CENTRAL and 18 EMBASE papers resulted in 6 publications that met the eligibility criteria. Data extraction provided no conclusive evidence that the application of $\mathrm{CHX}-\mathrm{V}$ is effective in patients when regular professional oral prophylaxis is performed. If effective, the $40 \% \mathrm{CHX}-\mathrm{V}$ was found to provide a benefit over a control or fluoride varnish. CHX-V at lower concentrations (1 and 10\%) may provide protection against root caries in high-risk patients (such as geriatric and xerostomia patients) in the absence of regular professional oral prophylaxis. Conclusion: Within the limitations of this review, it may be concluded
\end{abstract}

that in the absence of regular professional tooth cleaning and oral hygiene instructions, CHX-V may provide a beneficial effect in patients in need of special care. The strength of this recommendation is graded as 'weak'.

Copyright $\odot 2011$ S. Karger AG, Basel

Although root caries can be present in young individuals, its prevalence raises with increasing age, and root caries is thus a frequent problem among the dentate elderly [Banting et al., 1980]. The growing geriatric population in many developed countries is expected to retain their teeth into old age. Soft tissue recession due to age, traumatic toothbrushing habits, periodontal disease or periodontal treatment will unavoidably result in a higher number of tooth surfaces that are at risk for the development of root caries. According to epidemiologic studies, root caries is prevalent among patients with treated and untreated periodontal disease [Hix and O'Leary, 1976; Ravald and Hamp, 1981; Keltjens et al., 1988].

The development of caries on the root surface is associated with the composition and quantity of dental plaque, diet, the composition and flow of saliva, and exposure to fluoride [Ravald et al., 1986]. Adults with exposed root surfaces and with reduced salivary flow due

\section{KARGER}

Fax +41613061234 E-Mail karger@karger.ch www.karger.com
(C) 2011 S. Karger AG, Basel

0008-6568/11/0452-0162\$38.00/0

Accessible online at:

www.karger.com/cre
Dagmar Else Slot, Academic Centre for Dentistry Amsterdam (ACTA)

University of Amsterdam and VU University Amsterdam

Department of Periodontology, Gustav Mahlerlaan 3004

NL-1081 LA Amsterdam (The Netherlands)

Tel. +31 205980 179/307, E-Mail d.slot@acta.nl 
to medication are particularly at high risk for root surface caries [Banting et al., 2000].

Chlorhexidine (CHX) has been studied for over 30 years as an antimicrobial agent for the chemical control of plaque formation and for the prevention of caries. $\mathrm{CHX}$ is a strong base and it acts bacteriostatically when administered at low concentrations. At higher concentrations, CHX acts bactericidally. Its antibacterial spectrum covers Gram-positive and Gram-negative bacteria (the latter to a lesser extent), fungi and yeast. It is not a virucide, nor is it effective against acid- and alcohol-resistant bacilli [Emilson, 1977]. In general, the efficacy of CHX is related to its concentration and the frequency of application [Junco and Baca, 2005]. The vehicles most often used to administer $\mathrm{CHX}$ are mouth rinses, sprays, gels and varnishes. The inhibition of Streptococcus mutans was found to be the most persistent with $\mathrm{CHX}$ varnishes (CHX-V), followed by gels and mouthwashes [Emilson, 1994]. However, the higher effect on a surrogate outcome, i.e. inhibition of $S$. mutans, does not necessarily imply that $\mathrm{CHX}-\mathrm{V}$ has a stronger caries-inhibiting effect than CHX gels or mouthwashes [Hujoel, 2004].

Balanyk and Sandham [1985] first reported on the in vitro use of CHX-V against $S$. mutans, and in 1988, Sandham et al. [1988] published the first report of the use of $\mathrm{CHX}-\mathrm{V}$ in humans. CHX-V has advantages compared to other methods, since it is easily applied and does not result in the discoloration of teeth. One disadvantage of $\mathrm{CHX}-\mathrm{V}$ is the unpleasant flavor that can temporarily alter one's sense of taste [Matthijs and Adriaens, 2002].

The first systematic review on the effect of the antibacterial approach to prevent and control caries with special reference to the use of $\mathrm{CHX}-\mathrm{V}$ concluded that the evidence was inconclusive for the use of CHX-V for caries prevention in risk groups [Twetman, 2004]. A more recent systematic review on the reduction of caries with $\mathrm{CHX}-\mathrm{V}$ showed a moderate caries-inhibitory effect in children, adolescents and young adults when applied every 3-4 months [Zhang et al., 2006]. The most recent systematic review on the effectiveness of $\mathrm{CHX}-\mathrm{V}$ for preventing dental caries in children and adolescents concluded that the evidence regarding the effectiveness of $\mathrm{CHX}-\mathrm{V}$ compared to fluoride varnish (FV) for preventing caries is inconclusive [James et al., 2010]. However, a systematic quantitative evaluation of the effect of CHX$\mathrm{V}$, particularly on root surface caries, has not yet been performed. Therefore, this paper aimed to systematically evaluate the current literature to determine the effect of the use of $\mathrm{CHX}-\mathrm{V}$ on root caries incidence and activity.

Chlorhexidine Varnish and Root Caries

\section{Materials and Methods}

This systematic review was conducted in accordance with the guidelines of Transparent Reporting of Systematic Reviews and Meta-Analyses [PRISMA statement; Moher et al., 2009]. The question being focused on was as follows: what is the effect of $\mathrm{CHX}-\mathrm{V}$ on root caries, in a patient with gingival recessions?

\section{Search Strategy}

Three Internet sources were used to search for appropriate papers that satisfied the study purpose. These included the National Library of Medicine, Washington, D.C. (MEDLINE-PubMed), the Cochrane Central Register of Controlled Trials (CENTRAL) and EMBASE (Excerpta Medical Database by Elsevier). The databases were searched for studies conducted in the period up to and including December 23, 2010. The structured search strategy was designed to include any published paper that evaluated the effect of CHX-V on root caries (for details on the used search terms, see tables 1 and 2).

The following eligibility criteria were used:

- randomized controlled clinical trials (RCTs) or controlled clinical trials;

- papers written in English;

- conducted in humans;

- subjects $\geq 18$ years of age;

- intervention: CHX-V;

- control: placebo OR control treatment OR FV;

- clinical parameters: root caries incidence and/or root caries activity.

\section{Screening and Selection}

Two reviewers (D.E.S. and N.C.V.) independently screened titles and abstracts for eligible papers. If information relevant to the eligibility criteria was not available in the abstract, or if the title was relevant but the abstract was not available, the paper was selected for a full reading of the text. Next, full-text papers that fulfilled the eligibility criteria were identified and included into this study. The two reviewers hand-searched the reference lists of all of the selected studies for additional published papers that could possibly meet the eligibility criteria of this study. Papers that fulfilled all of the selection criteria were processed for data extraction.

The heterogeneity across the studies was detailed according to the following factors:

- type of varnish and comparison;

- application regimen and procedure;

- funding source;

- clinical indices.

\section{Quality Assessment}

Two reviewers (N.C.V. and D.E.S.) scored the methodological quality of the included studies. An assessment of the methodological study quality was performed as proposed by the RCT checklist of the Dutch Cochrane Center [2009] and was completed with quality criteria that were obtained from the CONSORT statement 2001 [CONSORT Group, 2009], Moher et al. [2001a, b, c], Needleman et al. [2005], the Jadad scale [Jadad et al., 1996] and the Delphi List [Verhagen et al., 1998]. Criteria were designated to each domain of internal validity, external validity, and statistical methods. 
Table 1. The following terms were used in the search strategy: Pubmed-MEDLINE and Cochrane-CENTRAL search

\section{Intervention}

$\{<$ chlorhexidine $[\mathrm{MeSH}]$ OR chlorhexidine OR chlorhexidine phosphanilate OR chlorhexidine di-gluconate OR chlorhexidine gluconate OR Zinc-chlorhexidine OR chlorhexidine gluconate lidocaine hydrochloride OR CHX OR CHX formulations [textwords])

AND

(varnish OR lacquer OR lac [textwords])>

OR

(EC40 OR Chlorzoin OR Bio C OR Cervitec OR Caries-ex [textwords])\}

AND

\section{Outcome}

\{Root Caries [Mesh] OR root caries OR root caries incidence $\mathrm{OR}$ root caries increment $\mathrm{OR}$ root caries activity [textwords]\}

Table 2. The following terms were used in the search strategy: EMBASE search

\section{Intervention}

[\{<chlorhexidine OR (chlorhexidine AND phosphanilate) OR (chlorhexidine AND di-gluconate) OR (chlorhexidine AND gluconate) OR (zinc AND chlorhexidine) OR (chlorhexidine AND gluconate AND lidocaine AND hydrochloride) OR CHX OR (CHX AND formulations)>

AND

$<$ varnish OR lacquer OR lac $>\}$

OR

$<$ EC40 OR Chlorzoin OR (Bio AND C) OR Cervitec OR (Caries AND ex) $>$ ]

AND

\section{Outcome}

[(root AND caries) OR (root AND caries AND incidence) OR (root AND caries AND activity)]
Each aspect of the score list was given a ' + ' sign for an informative description of the item at issue and a study design meeting the quality standard, a '-' sign for an informative description, but a study design not meeting the quality standard, and a '?' for lacking or insufficient information. If random allocation, defined eligibility criteria, blinding to patient and examiner, balanced experimental groups, an identical treatment between groups except for intervention and report of follow-up were present, the study was classified as having a low risk of bias. If 1 of these 6 criteria was missing, the study was considered to have a moderate potential risk of bias. If 2 or more of these criteria were missing, the study was considered to have a high potential risk of bias, as proposed by Van der Weijden et al. [2010]. In addition, the Centre for Evidence-Based Medicine levels of evidence [Centre for Evidence-Based Medicine, 2009] were used to assess the methodological quality. Score $1 \mathrm{a}$ is given to individual RCTs with a narrow confidence interval and $1 \mathrm{~b}$ - to individual RCTs with a wide confidence interval. Score $2 \mathrm{~b}$ is given to individual cohort studies, including low-quality RCTs (e.g. $<80 \%$ followup).

\section{Data Extraction}

Data from the papers that met the selection criteria were processed for analysis. Data were extracted with regard to the effect of $\mathrm{CHX}-\mathrm{V}$ in comparison to a placebo, a control treatment, or an FV. For studies that presented intermediate assessments, the baseline and final evaluations were used for this review. Mean values and standard deviations were extracted by D.E.S. and N.C.V.

Data Analysis

After a preliminary evaluation of the selected papers, it was found that considerable heterogeneity was present in the study designs, characteristics, outcome variables, and results. Where appropriate, a meta-analysis was performed and weighted mean differences were calculated by means of the Review Manager 4.2 software using a 'random effect' model (RevMan version 4.2 for Windows, Copenhagen, The Nordic Cochrane Centre, The Cochrane Collaboration, 2003). Only a few studies could be included to perform a valid quantitative analysis of the total body of evidence. Therefore, as a summary, also a descriptive manner of data presentation was used.

Any disagreement between the two reviewers (D.E.S. and N.C.V.) was resolved after additional discussion. If a disagreement persisted, the judgment of a third reviewer (G.A.W.) was decisive.

Grading the 'Body of Evidence'

The Grading of Recommendations Assessment, Development and Evaluation (GRADE) system as proposed by the GRADE working group was used for grading evidence emerging from this review [Guyatt et al., 2008; GRADE working group]. Two reviewers (D.E.S. and G.A.W.) rated the quality of the evidence and strength of recommendations on the following aspects: risk of bias of the individual studies, consistency and precision among the study outcomes, directness of the study results and the detection of publication bias. Any disagreement between the two reviewers was resolved after additional discussion; if a disagreement persisted, the judgment of a third reviewer (C.V.L.) was decisive. 
Fig. 1. Search and selection results.

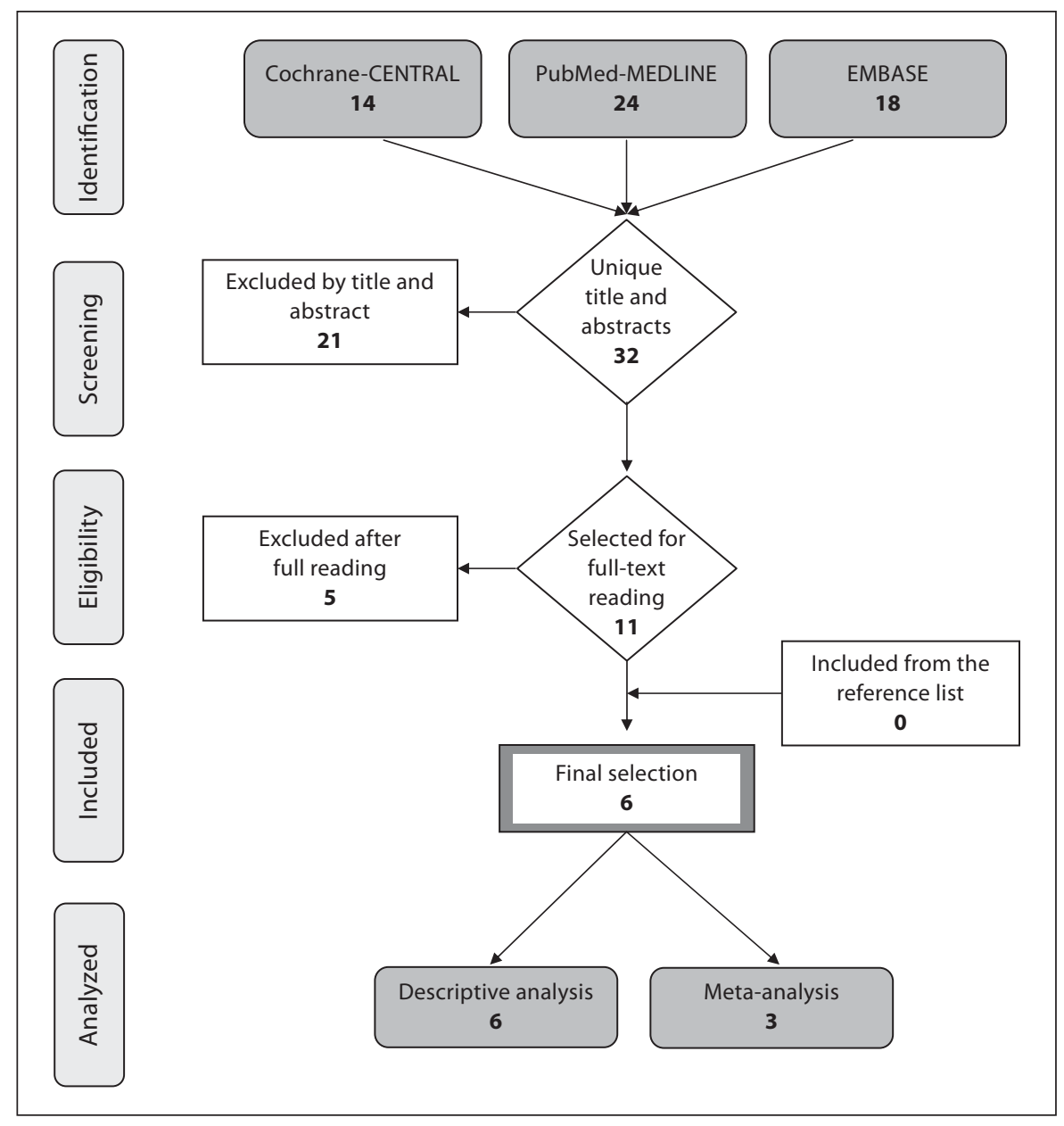

\section{Results}

\section{Search and Selection Results}

The searches resulted in 32 unique papers (for details, see fig. 1). The screening of titles and abstracts initially resulted in 11 full-text articles. In total, 5 papers were excluded after failing the eligibility criteria after a full-text reading. Two studies did not provide an appropriate intervention and control group [Brailsford et al., 2002; Wicht et al., 2003], 2 studies performed in situ research [Huizinga et al., 1990, 1991] and Ekenbäck et al. [2000] did not present clinical data on root caries. Consequently, 6 studies were identified as eligible for inclusion in this review according to the defined criteria for the study design, participants, intervention and outcome. These 6 trials, all experimental clinical studies, were processed for assessment of heterogeneity, quality assessment and data extraction.

Chlorhexidine Varnish and Root Caries

\section{Outcome Results}

\section{Assessment of Heterogeneity}

Information regarding the study characteristics, including study population and the medical and oral status of the subjects, is displayed in table 3 .

Type of Varnish and Comparison

Three different concentrations of CHX were used in the varnishes of the 6 selected studies: 1,10 and $40 \%$. When 1\% CHX-V was used (studies I, II, III, and IV), this was Cervitec ${ }^{\circledR}$ (Ivoclar Vivadent, Schaan, Liechtenstein). In study III, the CHX-V used was EC40 (Explore, Nijmegen, The Netherlands), containing 40\% CHX diacetate, while in study VI, a custom-made $40 \%$ (w/w) CHX-V was applied [Schaeken and De Haan, 1989]. In study V, a twostaged application was performed; first $1 \mathrm{ml}$ of either the active varnish or a placebo was used for treatment and this was followed by a second treatment with $1 \mathrm{ml}$ of poly- 
Table 3. Overview of the studies processed for data extraction

\begin{tabular}{|c|c|c|c|c|c|c|c|}
\hline $\begin{array}{l}\text { Study No., } \\
\text { reference }\end{array}$ & $\begin{array}{l}\text { Study design, } \\
\text { duration }\end{array}$ & $\begin{array}{l}\text { Number of } \\
\text { subjects at baseline } \\
\text { (end), age (mean/ } \\
\text { range), gender }\end{array}$ & $\begin{array}{l}\text { Inclusion/ } \\
\text { exclusion criteria }\end{array}$ & Groups & $\begin{array}{l}\text { Subjects } \\
\text { (sites) }\end{array}$ & $\begin{array}{l}\text { Application } \\
\text { regimen, OP, } \\
\text { OHI }\end{array}$ & Authors conclusion \\
\hline $\begin{array}{l}\text { I } \\
\text { Tan } \\
\text { et al. } \\
\text { [2010] }\end{array}$ & $\begin{array}{l}\text { RCT } \\
\text { Parallel } \\
\text { Single-blind } \\
3 \text { years }\end{array}$ & $\begin{array}{l}234^{\mathrm{a}}\left(152^{\mathrm{a}}\right) \\
\text { Mean: } 78.8^{\mathrm{a}} \\
\text { Range: ? } \\
\text { §:? } \\
\text { ?:? }\end{array}$ & $\begin{array}{l}\text { Elders living in residential and } \\
\text { nursing homes, at least } 5 \text { teeth with } \\
\text { exposed roots, no serious medical } \\
\text { problems, and basic self-care ability } \\
\text { (including oral hygiene practices) }\end{array}$ & $\begin{array}{l}\text { CHX-V 1\% } \\
\text { FV } \\
\text { Control }\end{array}$ & $\begin{array}{l}71(?) \\
80(?) \\
83(?)\end{array}$ & $\begin{array}{l}\text { Every } 3 \text { months } \\
\text { OP: after } \\
\text { baseline } \\
\text { examination if } \\
\text { necessary scaling } \\
\text { OHI: Yes }\end{array}$ & $\begin{array}{l}\text { Sodium FV, and } \\
\text { CHX-V were more } \\
\text { effective in preventing } \\
\text { new root } \\
\text { caries than giving } \\
\text { OHI alone }\end{array}$ \\
\hline $\begin{array}{l}\text { II } \\
\text { Baca } \\
\text { et al. } \\
\text { [2009] }\end{array}$ & $\begin{array}{l}\text { RCT } \\
\text { Parallel } \\
\text { Double-blind } \\
1 \text { year }\end{array}$ & $\begin{array}{l}68(46) \\
\text { Mean: } 76.8^{\mathrm{a}} \\
\text { Range: ? } \\
\delta: 16 \\
\text { †: } 30\end{array}$ & $\begin{array}{l}\text { Institutionalized elderly } \geq 65 \text { years, } \\
\text { possession of } \geq 6 \text { teeth; no serious } \\
\text { disease, no intake of antibiotics } \\
\text { during } 2 \text { weeks before the start of } \\
\text { the study }\end{array}$ & $\begin{array}{l}\text { CHX-V 1\% } \\
\text { Placebo }\end{array}$ & $\begin{array}{l}21(60) \\
25(65)\end{array}$ & $\begin{array}{l}\text { Week: } 1(2 x) \\
\text { Month: } \\
1,3,6,9,12 \\
\text { OP: } 30-45 \text { days } \\
\text { before the start } \\
\text { of the study } \\
\text { OHI: No }\end{array}$ & $\begin{array}{l}\text { Cervitec may help to } \\
\text { control established } \\
\text { root lesions and } \\
\text { reduce the incidence } \\
\text { of root caries lesion } \\
\text { among institutional- } \\
\text { ized elderly }\end{array}$ \\
\hline $\begin{array}{l}\text { III } \\
\text { Bizhang } \\
\text { et al. } \\
\text { [2007] }\end{array}$ & $\begin{array}{l}\text { RCT } \\
\text { Split-mouth } \\
\text { No blinding } \\
3 \text { years }\end{array}$ & $\begin{array}{l}33(29) \\
\text { Mean: } 53.99 \\
\text { Range: } 37-66 \\
\delta: 12 \\
\text { : } 21\end{array}$ & $\begin{array}{l}\text { Patients from a periodontal } \\
\text { maintenance program, } \geq 1 \text { tooth } \\
\text { with recession ( } \geq 2 \mathrm{~mm} \text { ) in each } \\
\text { quadrant with sound and intact root } \\
\text { surface; subjects considered in good } \\
\text { general health had } \geq 20 \text { natural teeth }\end{array}$ & $\begin{array}{l}\text { CHX-V } 40 \% \\
\text { CHX-V } 1 \% \\
\text { FV } \\
\text { Control }\end{array}$ & $\begin{array}{l}29(29) \\
29(29) \\
29(30) \\
29(29)\end{array}$ & $\begin{array}{l}\text { Every } 3 \text { months } \\
\text { OP: Yes, every } \\
3 \text { months } \\
\text { OHI: Yes, every } \\
3 \text { months }\end{array}$ & $\begin{array}{l}\text { Adjunctive chemo- } \\
\text { therapeutic agents } \\
\text { such as fluoride or } \\
\text { CHX did not provide } \\
\text { an additional benefit } \\
\text { over home care and } \\
\text { professional oral } \\
\text { hygiene procedures }\end{array}$ \\
\hline $\begin{array}{l}\text { IV } \\
\text { Johnson } \\
\text { and } \\
\text { Almqvist } \\
\text { [2003] }\end{array}$ & $\begin{array}{l}\text { RCT } \\
\text { Parallel } \\
\text { Single-blind } \\
18 \text { months }\end{array}$ & $\begin{array}{l}11(?) \\
\text { Mean: ? } \\
\text { Range: ? } \\
\delta: ? \\
\text { : ? }\end{array}$ & $\begin{array}{l}\text { Physically dependent patients with } \\
\text { superficial active primary root caries } \\
\text { lesions accessible for visual } \\
\text { inspection and photography }\end{array}$ & $\begin{array}{l}\text { CHX-V 1\% } \\
\text { Placebo }\end{array}$ & $\begin{array}{l}6(?) \\
5(?)\end{array}$ & $\begin{array}{l}\text { Two occasions } \\
\text { within a } 10 \text {-day } \\
\text { period, every } \\
3 \text { months } \\
\text { OP: Yes, every } \\
3 \text { months } \\
\text { OHI: ? }\end{array}$ & $\begin{array}{l}\text { In disabled and infirm } \\
\text { patients, regular } \\
\text { professional tooth } \\
\text { cleaning with a } \\
\text { fluoride containing } \\
\text { paste, with or without } \\
\text { supplementary } \\
\text { varnishing with CHX/ } \\
\text { thymol, and/or } \\
\text { fluoride, can prevent } \\
\text { further progression of } \\
\text { existing superficial } \\
\text { root caries lesions and } \\
\text { warrants further } \\
\text { investigation }\end{array}$ \\
\hline $\begin{array}{l}\text { V } \\
\text { Banting } \\
\text { et al. } \\
\text { [2000] }\end{array}$ & $\begin{array}{l}\text { RCT } \\
\text { Parallel } \\
\text { Double-blind } \\
13 \text { months }\end{array}$ & $\begin{array}{l}\text { ? }(156) \\
\text { Mean: ? } \\
\text { Range: ? } \\
\text { s:? } \\
\text { : ? }\end{array}$ & $\begin{array}{l}\text { Xerostomia (dry mouth) patients, } \\
45-75 \text { years, } \geq 10 \text { teeth, stable } \\
\text { medication, good oral health, }>10 \\
\text { surfaces requiring restorative } \\
\text { treatment, no recent fluoride } \\
\text { application, active untreated caries } \\
\geq 2 \text { filled surfaces in last } 2 \text { years }\end{array}$ & $\begin{array}{l}\text { CHX-V 10\% } \\
\text { Placebo }\end{array}$ & $\begin{array}{l}\text { (?) } 77 \\
\text { (?) } 79\end{array}$ & $\begin{array}{l}\text { Week: } 1,2,3,4 \\
\text { Month: } 6 \\
\text { OP: No } \\
\text { OHI: Yes, every } \\
\text { visit }\end{array}$ & $\begin{array}{l}\text { The results of this } \\
\text { study suggest that } \\
10 \% \text { CHX-V may } \\
\text { have an important } \\
\text { role to play in the } \\
\text { management of dental } \\
\text { caries in adults with } \\
\text { dry mouth }\end{array}$ \\
\hline $\begin{array}{l}\text { VI } \\
\text { Schaeken } \\
\text { et al. } \\
{[1991]}\end{array}$ & $\begin{array}{l}\text { RCT } \\
\text { Parallel } \\
\text { Double-blind } \\
1 \text { year }\end{array}$ & $\begin{array}{l}44(44) \\
\text { Mean: } 44.4 \\
\text { Range: ? } \\
\text { s:? } \\
\text { q:? }\end{array}$ & $\begin{array}{l}\text { Patients who had undergone } \\
\text { periodontal surgery } \geq 2 \text { years ago on } \\
\geq 6 \text { teeth, participated in a } \\
\text { maintenance program every } 3 \\
\text { months, and with } \geq 2 \text { decayed or } \\
\text { filled root surfaces }\end{array}$ & $\begin{array}{l}\text { CHX-V 40\% } \\
\text { FV } \\
\text { Control }\end{array}$ & $\begin{array}{l}16(62) \\
15(49) \\
13(29)\end{array}$ & $\begin{array}{l}\text { Every } 3 \text { months } \\
\text { OP: Yes every } \\
3 \text { months } \\
\text { OHI: ? }\end{array}$ & $\begin{array}{l}\text { After treatment with } \\
\mathrm{CHX}-\mathrm{V} \text {, significantly } \\
\text { more initial root } \\
\text { surface lesions had } \\
\text { hardened than in the } \\
\text { other groups }\end{array}$ \\
\hline
\end{tabular}

$\mathrm{OP}=$ Oral prophylaxis; $\mathrm{OHI}=$ oral hygiene instruction; ? = unknown.

${ }^{a}$ Calculated by the authors of this systematic review based on the presented data in the selected paper. 
urethane $29 \%(\mathrm{w} / \mathrm{v})$, ethyl acetate $22 \%(\mathrm{w} / \mathrm{v})$ and acetone $49 \%(\mathrm{w} / \mathrm{v})$. Both of the varnishes contained Benzoin Sumatra U.S.P. $20 \%(\mathrm{w} / \mathrm{v})$ and Alcohol Dehydrated U.S.P. to volume, while the active treatment contained $10 \%$ custom-made $\mathrm{CHX}$ acetate (w/v). The control groups received no intervention in studies III and VI, a placebo varnish in study II, water in study I and water flavored with eucalyptus oil in study IV. In studies I, III, and VI, the FV Duraphat ${ }^{\circledR}$ (Colgate-Palmolive, Piscataway, N.Y., USA) was used.

\section{Application Regimen and Procedure}

Individualized oral hygiene instruction was provided to each participant, focusing on effective brushing with a manual toothbrush, and use of fluoride toothpaste was recommended in study I. Before applications, a piece of gauze was used to clean and dry the teeth; the study agents were then applied onto the exposed root surfaces of participants in the respective groups by means of a disposable microbrush. The participants were instructed not to eat within half an hour after treatment. Applications of water were repeated every 12 months, and applications of $\mathrm{CHX}-\mathrm{V}$ or FV were repeated every 3 months (study I). In study II, the $1 \%$ CHX-V was applied by the same dentist with a portable equipment following the manufacturer's instructions. Briefly, the teeth were cleaned with a toothbrush for 2-3 min. The teeth were then isolated from saliva with cotton rolls and dried with compressed air, followed by the application of a thin coat of varnish to all teeth and surfaces using the brush supplied by the manufacturer. The varnish was gently dried by air for $30 \mathrm{~s}$. The subjects were then instructed not to eat or drink for $3 \mathrm{~h}$, not to clean their teeth until the following day, and not to use dental floss for 1 week. In study III, the $40 \% \mathrm{CHX}-\mathrm{V}$ or $1 \% \mathrm{CHX}-\mathrm{V}$ were applied to the root surface every 3 months after teeth cleaning and polishing with a fluoride paste and a rubber cup. The teeth receiving the varnish were isolated with cotton rolls, quadrant by quadrant, and then dried with an air syringe; the respective agents were applied with a disposable microbrush. According to the manufacturer's instructions, the $40 \% \mathrm{CHX}-\mathrm{V}$ was left in place for $8 \mathrm{~min}$ and then removed with a rubber cup, polishing paste, and dental floss. The subjects were instructed to avoid beverages or food for $2 \mathrm{~h}$ after the $1 \% \mathrm{CHX}-\mathrm{V}$ application; only water was allowed after $1 \mathrm{~h}$. The diet was not restricted following the application of the $40 \%$ $\mathrm{CHX}-\mathrm{V}$, according to the manufacturer's instructions. In study IV, there were two treatments with $1 \% \mathrm{CHX}-\mathrm{V}$ within 10 days, and then every 3 months for 18 months. The varnishes were applied by the same dental hygienist in ac- cordance with the manufacturer's recommendation for Cervitec. In study V, the $10 \% \mathrm{CHX}-\mathrm{V}$ was applied once weekly for 4 consecutive weeks after screening and testing, and then a single reapplication was performed after 6 months by a dental hygienist. The application was performed following a predetermined, but unspecified protocol. In study VI, the varnish was applied every 3 months after the periodontal checkup and professional tooth cleaning of the maintenance program. The varnishes were applied on dried root surfaces with a small firm brush and with a blunt dental instrument (Ash No. 6). After treatment, the subjects were allowed to rinse with tap water. Then, excess varnish on the mucosa was removed with the blunt dental instrument.

\section{Funding Source}

Four studies mentioned sponsoring and funding. The Hong Kong Research Grants Council supported study I. Vivadent Laboratories supplied the varnishes for study II. This study was also partially funded by Research Group CTS-167 (Consejería de Educación y Ciencia, Junta de Andalucía, Spain) and Fondo de Investigaciones Sanitarias, Spain. Study IV was funded by The Swedish Patent Revenue Fund for Research in Preventive Dentistry. Two companies supported study V: Vivadent-Vivacare, Schaan, Liechtenstein (1\% CHX and saliva tests) and GABA, Basel, Switzerland (toothpaste).

\section{Indices}

Root Caries Incidence Measured by Decayed, Missed and Filled Root Surfaces. Active root caries in study I was recorded when a lesion on the root surface could be easily penetrated by a sharp sickle-shaped probe with light force according to Banting [2001]. In studies II and VI, the number of exposed root surfaces per tooth was recorded, and the decayed and filled root surfaces were scored. In study III, root caries was recorded on exposed facial root surfaces. In study $\mathrm{V}$, caries was scored according to the adaptation by Pitts and Fyffe [1988] of the WHO caries terminology that was expanded to include root caries. The caries increment score was expressed as new (primary or secondary) carious root surfaces per subject. The caries increment was determined using a pairwise matrix that contrasts the status of a tooth surface at the baseline examination with its status at each of the subsequent visits.

Root Caries Activity Measured by Texture. In study II, the variables described by Brailsford et al. [2002] based on Beighton's methods [Beighton et al., 1993] were recorded for the texture of each root lesion and designated 
Table 4. Methodological quality scores of the included studies

\begin{tabular}{|c|c|c|c|c|c|c|}
\hline \multirow[t]{2}{*}{ Quality criteria } & \multicolumn{6}{|l|}{ Study } \\
\hline & I & II & III & IV & $\mathrm{V}$ & VI \\
\hline \multicolumn{7}{|l|}{ Internal validity } \\
\hline Random allocation* & + & + & + & + & + & + \\
\hline Allocation concealment & + & $?$ & $?$ & $?$ & $?$ & $?$ \\
\hline Blinded to patient* & $?$ & - & $?$ & + & + & + \\
\hline Blinded to examiner* & + & - & + & + & + & + \\
\hline Blinding during statistical analysis & $?$ & $?$ & $?$ & + & $?$ & $?$ \\
\hline Balanced experimental groups* & + & $?$ & $?$ & + & $?$ & - \\
\hline Reported loss to follow-up* & + & + & + & + & + & + \\
\hline Number $(\%)$ of dropouts & $82^{\mathrm{a}}\left(35 \%^{\mathrm{a}}\right)$ & $4(12.1 \%)$ & $?$ & $22(32.4 \%)$ & $?$ & 0 \\
\hline Treatment identical, except for intervention* & + & + & + & + & + & + \\
\hline \multicolumn{7}{|l|}{ External validity } \\
\hline Representative population group & - & + & - & - & - & + \\
\hline Eligibility criteria defined ${ }^{*}$ & + & + & + & + & + & + \\
\hline \multicolumn{7}{|l|}{ Statistical validity } \\
\hline Sample size calculation and power & + & + & $?$ & + & $?$ & + \\
\hline Point estimates & + & - & - & + & + & + \\
\hline Measures of variability presented for the primary outcome & + & - & - & + & + & - \\
\hline Include an intention-to-treat analysis & + & $?$ & $?$ & $?$ & + & $?$ \\
\hline Authors estimated risk of bias & moderate & moderate & moderate & moderate & moderate & low \\
\hline Level of evidence (CEBM) & $1 \mathrm{~b}$ & $1 b-$ & $2 b-$ & $2 b-$ & $2 b-$ & $1 b-$ \\
\hline
\end{tabular}

$?=$ Not specified/unclear; + = yes; $-=$ no; ${ }^{*}=$ reporting criteria for estimating the potential risk of bias; ${ }^{\text {a }}$ calculated by the authors of this systematic review based on the presented data in the selected paper.

as hard, leathery or soft. In study III, the apparent lesions were judged as active when greasy, yellowish or light brownish, and soft upon light probing. Lesions were assumed to be inactive when the color was brownish or dark, smooth, and sound upon probing [Nyvad and Fejerskov, 1986]. In study IV, the root caries lesions were inspected under normal operation lighting after cleaning and drying with a blast of air. The lesions were then spot probed using new, sharp examination probes (SSW No. 5, Nordenta AB, Enköping, Sweden). The root caries lesions were denoted as active or inactive based on the following visual and tactile criteria: $1=$ a hard lesion with a highly polished surface (inactive lesion); 2 = a somewhat softened lesion with a dull surface (active lesion), and $3=$ a soft lesion with a dull rough surface (active lesion). Caries activity was assessed by evaluation of changes in the hardness of initial root lesions. Changes in hardness were measured by means of a small spoon excavator in study VI. When the lesion was easy to penetrate, and a small spoon excavator $(\varnothing=1.0 \mathrm{~mm})$ could remove carious dentin with moderate pressure, the lesion was considered to be soft; otherwise the lesion was considered to be hard.
Lesions were differentiated into initial lesions (depth $<0.5$ $\mathrm{mm}$ ) and advanced lesions (depth $>0.5 \mathrm{~mm}$ ).

\section{Study Quality}

Quality assessment values, including the internal, external, and statistical validity, are presented in table 4 . Based on a summary of these criteria, the estimated potential risk of bias is low for only 1 study (VI) and moderate for 5 studies (I, II, III, IV, and V). The individual score of the Centre for Evidence-Based Medicine levels of evidence is $1 b$ - for studies III and VI. Due to $>20 \%$ or unknown amount of loss to follow-up of subjects, the level is $2 \mathrm{~b}$ for the other studies (I, II, IV, and V). All but 1 study (I) failed to provide data concerning the confidence interval and therefore a minus sign is added to the level of evidence.

\section{Study Outcomes}

Changes within Groups during the Course of the

Study

Information regarding the study outcomes is presented in table 5. With respect to root caries incidence measured by decayed, missed and filled root surfaces, table $5 \mathrm{a}$ 
Table 5. Root caries incidence and root caries activity

a Root caries incidence measured by DMF-RS (mean $\pm \mathrm{SD}$ )

\begin{tabular}{|c|c|c|c|c|c|}
\hline Study & Index & Group & Base & End & Difference \\
\hline I & New active caries or fillings & $\begin{array}{l}\text { CHX-V 1\% } \\
\text { FV } \\
\text { Control }\end{array}$ & $\begin{array}{l}1.8 \pm 2.97^{\mathrm{a}} \\
2.4 \pm 2.77^{\mathrm{a}} \\
2.2 \pm 2.8^{\mathrm{a}}\end{array}$ & $\begin{array}{l}2.9^{\mathrm{a}} \\
3.3^{\mathrm{a}} \\
4.7^{\mathrm{a}}\end{array}$ & $\begin{array}{l}1.1 \pm 3.70^{\mathrm{a}} \\
0.9 \pm 1.39^{\mathrm{a}} \\
2.5 \pm 2.1^{\mathrm{a}}\end{array}$ \\
\hline II & New root caries & $\begin{array}{l}\text { CHX-V 1\% } \\
\text { Placebo }\end{array}$ & $\begin{array}{l}2.86 \pm 2.01 \\
2.60 \pm 1.32\end{array}$ & $\begin{array}{l}3.53^{\mathrm{a}} \\
3.92^{\mathrm{a}}\end{array}$ & $\begin{array}{l}+0.67 \pm 0.73 \\
+1.32 \pm .22\end{array}$ \\
\hline III & New carious root surface lesion & $\begin{array}{l}\text { CHX-V 40\% } \\
\text { CHX-V 1\% } \\
\text { FV } \\
\text { Control }\end{array}$ & $\begin{array}{l}? \\
? \\
? \\
?\end{array}$ & $\begin{array}{l}? \\
? \\
? \\
?\end{array}$ & $\begin{array}{l}0 \\
0 \\
0 \\
0\end{array}$ \\
\hline $\mathrm{V}$ & Root caries increment & $\begin{array}{l}\text { CHX-V } 10 \% \\
\text { Placebo }\end{array}$ & $\begin{array}{l}? \\
?\end{array}$ & $\begin{array}{l}? \\
?\end{array}$ & $\begin{array}{l}+0.77 \pm 1.33 \\
+1.30 \pm 1.70\end{array}$ \\
\hline VI & Absolute number of decayed root surfaces & $\begin{array}{l}\text { CHX-V } 40 \% \\
\text { FV } \\
\text { Control }\end{array}$ & $\begin{array}{l}93 \\
66 \\
32\end{array}$ & $\begin{array}{l}95 \\
70 \\
45\end{array}$ & $\begin{array}{l}+2^{\mathrm{a}} \\
+4^{\mathrm{a}} \\
+13^{\mathrm{a}}\end{array}$ \\
\hline VI & Absolute number of filled root surfaces & $\begin{array}{l}\text { CHX-V } 40 \% \\
\text { FV } \\
\text { Control }\end{array}$ & $\begin{array}{l}28 \\
23 \\
25\end{array}$ & $\begin{array}{l}38 \\
27 \\
31\end{array}$ & $\begin{array}{l}+10^{\mathrm{a}} \\
+4^{\mathrm{a}} \\
+6^{\mathrm{a}}\end{array}$ \\
\hline VI & Absolute number DMF-RS & $\begin{array}{l}\text { CHX-V } 40 \% \\
\text { FV } \\
\text { Control }\end{array}$ & $\begin{array}{r}121^{\mathrm{a}} \\
89^{\mathrm{a}} \\
57^{\mathrm{a}}\end{array}$ & $\begin{array}{r}133^{\mathrm{a}} \\
97^{\mathrm{a}} \\
76^{\mathrm{a}}\end{array}$ & $\begin{array}{l}+12 \\
+10 \\
+20\end{array}$ \\
\hline
\end{tabular}

b Root caries activity measured by texture

\begin{tabular}{|c|c|c|c|c|c|}
\hline Study & Index & Group & Base & End & Difference \\
\hline \multirow[t]{2}{*}{ II } & \multirow[t]{2}{*}{ Changes in texture of initial lesions: softened } & CHX-V $1 \%$ & ? & ? & $0 \%^{\mathrm{a}}$ \\
\hline & & Placebo & $?$ & $?$ & $+8 \%^{\mathrm{a}}$ \\
\hline \multirow[t]{2}{*}{ IV } & \multirow[t]{2}{*}{ Changes in texture of initial lesions: softened } & CHX-V 1\% & ? & ? & ? \\
\hline & & Placebo & $?$ & $?$ & $?$ \\
\hline \multirow[t]{3}{*}{ VI } & \multirow[t]{3}{*}{ Changes in texture of initial lesions: softened } & $\mathrm{CHX}-\mathrm{V} 40 \%$ & ? & $?$ & $+2 \%$ \\
\hline & & $\mathrm{FV}$ & $?$ & $?$ & $+6 \%$ \\
\hline & & Control & $?$ & $?$ & $+10 \%$ \\
\hline \multirow[t]{2}{*}{ II } & \multirow{2}{*}{ Changes in texture of initial lesions: hardened } & CHX-V 1\% & ? & ? & $+28 \%^{\mathrm{a}}$ \\
\hline & & Placebo & $?$ & $?$ & $+17 \%^{\mathrm{a}}$ \\
\hline \multirow[t]{3}{*}{ VI } & \multirow[t]{3}{*}{ Changes in texture of initial lesions: hardened } & CHX-V $40 \%$ & ? & ? & $+15 \%$ \\
\hline & & FV & $?$ & $?$ & $+11 \%$ \\
\hline & & Control & $?$ & $?$ & $+3 \%$ \\
\hline \multirow[t]{4}{*}{ III } & \multirow[t]{4}{*}{ Nyvad and Fejerskov [1986] } & CHX-V 40\% & $?$ & $?$ & ? \\
\hline & & CHX-V 1\% & $?$ & $?$ & $?$ \\
\hline & & FV & $?$ & ? & ? \\
\hline & & Control & $?$ & $?$ & $?$ \\
\hline
\end{tabular}

DMF-RS = Decayed, missed and filled root surfaces.

${ }^{a}$ Calculated by the authors of this review based on the presented data in the selected paper. 
Table 6. A summary of statistical significance of the comparisons between the control, placebo or FV, and the CHX-V intervention

\begin{tabular}{lllll}
\hline Study No. & CHX, \% $\begin{array}{l}\text { Caries } \\
\text { incidence }\end{array}$ & $\begin{array}{l}\text { Caries } \\
\text { activity }\end{array}$ & Comparison \\
\hline III & 40 & 0 & $?$ & control \\
VI & 40 & + & + & control \\
III & 40 & 0 & $?$ & FV \\
VI & 40 & $?$ & + & FV \\
V & 10 & + & - & placebo \\
II & 1 & + & + & placebo \\
IV & 1 & - & 0 & placebo \\
III & 1 & 0 & $?$ & control \\
I & 1 & + & - & control \\
I & 1 & 0 & - & FV \\
III & 1 & 0 & $?$ & FV \\
\hline
\end{tabular}

$+=$ Significant difference in favor of intervention; $0=$ no significant difference; - = no data available; ? = inconclusive data which does not allow to draw conclusions concerning statistical significance.

shows the results from the data extraction on the incidence of caries. Four studies (I, II, V, and VI) showed an increase in caries incidence in all groups, while study III did not find any incidence of caries in any group. With respect to root caries activity measured by texture, table $5 \mathrm{~b}$ presents the changes in the texture of initial lesions, whether they were softened or hardened. All 4 studies (II, III, IV, and VI) do not provide baseline or end trial scores. Only in studies II and VI are data concerning the increment presented, showing softening of lesions in all of the groups, and up to $10 \%$ in the control group. In these studies, hardening of lesions was observed in all of the CHX-V groups (ranging from 15 to $28 \%$ ). For study III, the outcome data were unclear.

\section{Comparison between Groups upon Completion of} the Study

Table 6 presents a summary of the descriptive data on whether there are significant differences between the intervention and the control, placebo or FV groups. Two studies observed a periodontal maintenance population (III and VI). One study (III), with 2 comparisons (CHX-V vs. both control and FV) and 2 different concentrations of CHX-V (1 and 40\%) showed no difference in effect. One study (VI) with 40\% CHX-V showed a significant positive effect on root caries activity $(\mathrm{p}<0.05)$ and root caries incidence $(\mathrm{p}<0.01)$ as compared to the control. In a xerostomia population, study $\mathrm{V}$ showed a positive effect on root caries incidence $(\mathrm{p}=0.02)$ with $10 \% \mathrm{CHX}-\mathrm{V}$ compared to the placebo.

In a geriatric population, study II testing CHX-V $1 \%$ observed a positive significant effect on root caries activity $(\mathrm{p}=0.036)$ and root caries incidence $(\mathrm{p}=0.039)$ as compared to a placebo varnish.

In an elderly, physically dependent population, study IV showed no effect on root caries activity for a $1 \%$ CHX$\mathrm{V}$ as compared to placebo, whereas study I did show an effect on root caries incidence ( $\mathrm{p}=0.001$ ) as compared to a control, but no significant difference from FV.

\section{Meta-Analysis}

The data set allowed a meta-analysis concerning root caries incidence including 3 studies (I, II, and V). Studies I and II evaluated $1 \% \mathrm{CHX}-\mathrm{V}$ in an elderly population and study $\mathrm{V}$ used $10 \% \mathrm{CHX}-\mathrm{V}$ in xerostomia patients. The overall weighted mean difference between the CHX-V and control/placebo was 0.65 in favor of the CHX-V ( $\mathrm{p}=$ $0.0003,95 \%$ CI -1.01 to -0.30$)$.

Grading the 'Body of Evidence'

Since the data are inconsistent with on average a 'moderate estimated risk of bias', the precision is undeterminable to moderate and the study results are not generalizable. The strength of the recommendation to use CHX-V is considered to be 'weak' for both caries incidence and activity.

\section{Discussion}

A systematic review, by virtue of the method used to collect information, provides a solid base for clinical decision-making [Newman et al., 2003], due to its high level of evidence. It is a systematic assessment of the available literature for the effects of health care interventions, and is an assessment that is intended to help professionals in choosing the appropriate treatment.

Root surface caries is a common problem encountered in dental patients and has increasing implications for public health [Griffin et al., 2004]. The etiologic bacteria for initiation and progression of root caries have been investigated. Initially, Actinomyces was believed to be the pathogen responsible for initiating root caries [Jordan and Hammond, 1972; Summney and Jordan, 1974; Syed et al., 1975]. More recently, S. mutans and lactobacilli have also been considered to contribute to root caries [Emilson et al., 1988; Bowden et al., 1990; Lynch and Beighton, 1994]. Collectively, a complex of 
microbiota may facilitate the pathogenesis of root caries.

CHX has a broad antibacterial effect [Emilson, 1977] because $S$. mutans is particularly sensitive to this compound, which also inhibits plaque formation and acid production by plaque [Johnson and Almqvist, 2003]. $\mathrm{CHX}$ can be effective in reducing the number of $S$. $m u$ tans in dental plaque and in inhibiting the development of fissure caries when applied to the tooth surfaces as a varnish. A persistent reduction of $S$. mutans was shown to depend on the concentration of CHX. After comparing the effects of $10 \% \mathrm{CHX}, 20 \% \mathrm{CHX}$, and $40 \% \mathrm{CHX}$ over 22 weeks, only the $40 \% \mathrm{CHX}-\mathrm{V}$ was found to reduce the number of $S$. mutans in fissures [Schaeken et al., 1989]. Applying 40\% CHX-V twice a year on pits and fissures of permanent first molars of 6- to 7-year-old children can significantly reduce the number of $S$. mutans for a 6-month period, but the reductions were small [Zhang et al., 2007].

The aim of this review was to determine whether $\mathrm{CHX}-\mathrm{V}$ is an appropriate intervention to prevent or treat root caries in patients with recessions. This paper focuses on the effect of $\mathrm{CHX}-\mathrm{V}$ on the clinical indices of root caries. This research excluded literature that deals with surrogate end points, such as the effect of an antimicrobial agent on the level of $S$. mutans or plaque reduction. These outcome measures do not always correlate with an eventual reduction in caries [Caufield et al., 2001; Dasanayake et al., 2002; Anderson, 2003].

Comparison of the results from the selected studies was difficult because there was considerable variation in the study parameters, such as clinical indices, varnishes with different $\mathrm{CHX}$ concentrations, inclusion/exclusion criteria for the subjects and application regime. This posed a serious restriction on this attempt to review the literature in a quantitative, systematic manner. Active and inactive root caries lesions have been described by several investigators [Balanyk and Sandham, 1985; Sandham et al., 1988; Emilson, 1994; Matthijs and Adriaens, 2002]. The prime distinguishing features are the texture of the lesion and the presence of a visible plaque. It has been claimed that active root caries feels softened or leathery upon probing with moderate pressure. Inactive root caries has been stated to have a dark brownish or black discoloration, and typically a smooth and shiny surface that is hard upon probing with moderate pressure. The use of the 'softness' criterion to define active lesions has been validated by the presence of microbes that are assumed to be actively advancing the lesion [Beighton et al., 1993]. Four of the 6 included studies used hardness as root caries activity criterion (II, III, IV, and VI).

None of the included publications compared CHX-V with and without professional tooth cleaning. In the study III by Bizhang et al. [2007], the oral hygiene levels of the patients improved continuously over the 3 -year duration of the study. In addition, these periodontal maintenance patients received professional plaque control measures every 3 months. Neither root nor coronal caries developed 'de novo' during the study period in any of the groups. In study VI, including a periodontal recall population receiving 3-monthly maintenance, a positive effect on root caries activity was observed with $40 \% \mathrm{CHX}-\mathrm{V}$. This outcome is in contrast to study III, which may be the result of unbalanced groups at baseline (VI) or the absence of blinding (III). The divergence between the outcomes of these 2 studies implies that it remains inconclusive whether CHX-V has a beneficial effect in the presence of regular prophylaxis in a periodontal maintenance population.

In study IV with a population in need of special care out of 11 patients, with a 3-month professional prophylaxis for all of the groups, only 1 patient showed progression of existing lesions at the end of the 12 months' evaluation [Johnson and Almqvist, 2003]. This is not surprising since the efficiency of plaque control on caries development is well established from a long-term study of 30 years [Axelsson et al., 2004]. One study (V) in a xerostomia population did not provide professional tooth cleaning on a regular basis, and the 2 other studies (I, and II) in a geriatric population provided only a single oral prophylaxis. All these studies with no or limited prophylaxis showed that CHX-V (1-10\%) may provide a benefit in the prevention of root caries. One should also recognize that the frequency of application of the CHX-V may be important for its anticaries efficacy [Zhang et al., 2006]. However, the number of studies included in the present review was too small to analyze the frequency of application as a covariable in regression analysis.

Within the limitations of this review, it may be concluded that when professional tooth cleaning and hygiene instructions are regularly followed, little to no additional effect of CHX-V is evident. However, the meta-analysis showed that $\mathrm{CHX}-\mathrm{V}$ may have a place in high-risk patients such as the elderly or those with xerostomia (I, II, and V). A recent review [Heijnsbroek et al., 2007] evaluated the effect of fluoride intervention on root caries. The evidence from this work suggests that increasing the regular daily orally delivered fluoride has a beneficial effect on the reduction of root caries incidence and activity. 
When dealing with root caries, and when additional chemotherapeutic treatment is considered, rinsing with a fluoride-containing mouth rinse appears to be the intervention of choice [Wallace et al., 1993; Heijnsbroek et al., 2007]. This does not, of course, exclude the possibility that supplementary varnishing with both fluoride and $\mathrm{CHX}$ can be a valuable adjunct for the control of root caries progression [Johnson and Almqvist, 2003].

The strength of the recommendations which emerge from this review was rated according to GRADE. The GRADE working group provides a system for rating the quality of evidence and strength of recommendations that are explicit, comprehensive, transparent, and pragmatic [Guyat et al., 2008]. Evidence based on RCTs is generally considered as high-quality evidence. However, the confidence in the evidence may decrease based on various factors, including risk of bias, inconsistency of results, directness of evidence, imprecision and publication bias. The GRADE system offers two grades of strength in recommendations: 'strong' or 'weak' [Guyat et al., 2008]. Overall the quality of evidence emerging from this review considering the use of $\mathrm{CHX}-\mathrm{V}$ can be considered as 'weak'.

\section{Conclusion}

Within the limitations of this review, it may be concluded that in the absence of regular professional tooth cleaning and oral hygiene instructions, CHX-V may provide a beneficial effect for patients in need of special care. The strength of this recommendation is graded as 'weak'.

\section{Disclosure Statement}

The authors declare that they have no conflict of interest. This study was self-funded by the authors and their institutions.

\section{References}

Anderson MH: A review of the efficacy of chlorhexidine on dental caries and the caries infection. J Calif Dent Assoc 2003;31:211214.

Axelsson P, Nyström B, Lindhe J: The long-term effect of a plaque control program on tooth mortality, caries and periodontal disease in adults. Results after 30 years of maintenance. J Clin Periodontol 2004;31:749-757.

- Baca P, Clavero J, Baca AP, González-Rodríguez MP, Bravo M, Valderrama MJ: Effect of chlorhexidine-thymol varnish on root caries in a geriatric population: a randomized double-blind clinical trial. J Dent 2009;37:679685.

Balanyk TE, Sandham HJ: Development of sustained-release antimicrobial dental varnishes effective against Streptococcus mutans in vitro. J Dent Res 1985;64:1356-1360.

Banting DW: The diagnosis of root caries. J Dent Educ 2001;65:991-996.

-Banting DW, Ellen RP, Fillery ED: Prevalence of root surface caries among institutionalized older persons. Community Dent Oral Epidemiol 1980;2:84-88.

-Banting DW, Papas A, Clark DC, Proskin HM, Schultz M, Perry R: The effectiveness of $10 \%$ chlorhexidine varnish treatment on dental caries incidence in adults with dry mouth. Gerodontology 2000;17:67-76.

- Beighton D, Lynch E, Heath MR: A microbiological study of primary root-caries lesions with different treatments needs. J Dent Res $1993 ; 72: 623-629$.
Bizhang M, Chun YH, Heisrath D, Purucker P, Singh P, Kersten T, Zimmer S: Microbiota of exposed root surfaces after fluoride, chlorhexidine, and periodontal maintenance therapy: a 3-year evaluation. J Periodontol 2007;78:1580-1589.

Bowden GH, Ekstrand J, McNaughton B, Challacombe SJ: Association of selected bacteria with the lesions of root surface caries. Oral Microbiol Immunol 1990;5:346-351.

Brailsford SR, Fiske J, Gilbert S, Clark D, Beighton D: The effects of the combination of chlorhexidine/thymol- and fluoride-containing varnishes on the severity of root caries lesions in frail institutionalised elderly people. J Dent 2002;30:319-324.

Caufield PW, Dasanayake AP, Li Y: The antimicrobial approach to caries management. J Dent Educ 2001;65:1091-1095.

Centre for Evidence-based Medicine, University of Oxford (UK): Levels of evidence. 2009. http://www.cebm.net/index.aspx?o=1025.

CONSORT Group: The CONSORT statement 2001 - Checklist: items to include when reporting a randomized trial. 2009. http:// www.consort-statement.org/consort-statement.

Dasanayake AP, Wiener HW, Li Y, Vermund SV, Caufield PW: Lack of effect of chlorhexidine varnish on Streptococcus mutans transmission and caries in mothers and children. Caries Res 2002;36:288-293.

Dutch Cochrane Center: RCT-checklist. 2009. http://www.cochrane.nl/Files/documents/ Checklists/RCT.pdf.
Ekenbäck SB, Linder LE, Lönnies H: Effect of four dental varnishes on the colonization of cariogenic bacteria on exposed sound root surfaces. Caries Res 2000;34:70-74.

Emilson CG: Susceptibility of various microorganisms to chlorhexidine. Scand J Dent Res 1977;85:255-265.

Emilson CG: Potential efficacy of chlorhexidine against mutans streptococci and human dental caries. J Dent Res 1994;73:682-691.

-Emilson CG, Klock B, Sanford CB: Microbial flora associated with presence of root surface caries in periodontally treated patients. Scand J Dent Res 1988;96:40-49.

GRADE Working Group, Grading of Recommendations Assessment, Development and Evaluation (short GRADE) Working Group. http://www.gradeworkinggroup.org/index. htm.

Griffin SO, Griffin PM, Swann JL, Zlobin N: Estimating rates of new root caries in older adults. J Dent Res 2004;83:634-638.

Guyatt GH, Oxman AD, Vist GE, Kunz R, FalckYtter Y, Alonso-Coello P, Schünemann HJ, GRADE Working Group: GRADE: an emerging consensus on rating quality of evidence and strength of recommendations. BMJ 2008;26:924-926.

Heijnsbroek M, Paraskevas S, Van der Weijden GA: Fluoride interventions for root caries: a review. Oral Health Prev Dent 2007;5:145152.

Slot et al. 
-Hix JO, O’Leary TJ: The relationship between cemental caries, oral hygiene status and fermentable carbohydrate intake. J Periodontol 1976;47:398-404.

Huizinga ED, Ruben J, Arends J: Effect of an antimicrobial-containing varnish on root demineralisation in situ. Caries Res 1990;24: 130-132.

Huizinga ED, Arends J: The effect of an antimicrobial releasing varnish on root demineralisation in situ. The influence of the demineralisation period. J Biol Buccale 1991;19:2933.

Hujoel PP: Endpoints in periodontal trials: the need for an evidence-based research approach. Periodontol 2000 2004;36:196-204.

-Jadad AR, Moore RA, Carroll D, Jenkinson C, Reynolds DJ, Gavaghan DJ, McQuay HJ: Assessing the quality of reports of randomized clinical trials: is blinding necessary? Control Clin Trials 1996;17:1-12.

James P, Parnell C, Whelton H: The caries-preventive effect of chlorhexidine varnish in children and adolescents: a systematic review. Caries Res 2010;44:333-340.

-Johnson G, Almqvist H: Non-invasive management of superficial root caries lesions in disabled and infirm patients. Gerodontology 2003;20:9-14.

- Jordan HV, Hammond BF: Filamentous bacteria isolated from human root surface caries. Arch Oral Biol 1972;17:1333-1342.

Junco MP, Baca P: Métodos de control de placa bacteriana; in Cuenca Sala E, Baca García P (eds): Odontología preventiva y comunitaria. Principios, métodos y aplicaciones. Barcelona, Masson, 2005, pp 87-104.

Keltjens H, Schaeken T, van der Hoeven H, Hendriks J: Epidemiology of root surface caries in patients treated for periodontal diseases. Community Dent Oral Epidemiol 1988;16: 171-174.

- Lynch E, Beighton D: A comparison of primary root caries lesions classified according to colour. Caries Res 1994;28:233-239.

-Matthijs S, Adriaens PA: Chlorhexidine varnishes: a review. J Clin Periodontol 2002;29:1-8.

- Moher D, Schulz KF, Altman D, CONSORT Group (Consolidated Standards of Reporting Trials): The CONSORT statement: revised recommendations for improving the quality of reports of parallel-group randomized trials. JAMA 2001a;285:1987-1991.
- Moher D, Schulz KF, Altman DG: The CONSORT statement: revised recommendations for improving the quality of reports of parallel-group randomised trials. Lancet 2001b;357:1191-1194.

Moher D, Schulz KF, Altman DG, CONSORT: The CONSORT statement: revised recommendations for improving the quality of reports of parallel group randomized trials. BMC Med Res Methodol 2001c;1:2.

Moher D, Liberati A, Tetzlaff J, Altman DG, PRISMA Group: Preferred reporting items for systematic reviews and meta-analyses: the PRISMA statement. PLoS Med 2009; 7:e1000097.

Needleman I, Moles DR, Worthington H: Evidence-based periodontology, systematic reviews and research quality. Periodontol 2000 2005;37:12-28.

Newman MG, Caton JG, Gunsolley JC: The use of the evidence-based approach in a periodontal therapy contemporary science workshop. Ann Periodontol 2003;8:1-11.

Nyvad B, Fejerskov O: Active root surface caries converted into inactive caries as a response to oral hygiene. Scand J Dent Res 1986;94: 281-284.

$\checkmark$ Pitts NB, Fyffe HE: The effect of varying diagnostic thresholds upon clinical caries data for a low prevalence group. J Dent Res 1988, 67:592-596

PRISMA statement, Preferred Reporting Items for Systematic Reviews and Meta-Analyses. http://www.prisma-statement.org/.

Ravald N, Hamp SE: Prediction of root surface caries in patients treated for advanced periodontal disease. J Clin Periodontol 1981;8: 400-414.

Ravald N, Hamp SE, Birkhed D: Long-term evaluation of root surface caries in periodontally treated patients. J Clin Periodontol 1986;13: 758-767.

Sandham HJ, Brown J, Phillips HI, Chan KH: A preliminary report of long-term elimination of detectable mutans streptococci in man. Dent Res 1988;67:9-14.

Schaeken MJ, De Haan P: Effects of sustainedrelease chlorhexidine acetate on the human dental plaque flora. J Dent Res 1989;68:119123.
Schaeken MJ, Keltjens HM, Van Der Hoeven JS: Effects of fluoride and chlorhexidine on the microflora of dental root surfaces and progression of root-surface caries. J Dent Res 1991;70:150-153.

-Schaeken MJ, van der Hoeven JS, Hendriks JC: Effects of varnishes containing chlorhexidine on the human dental plaque flora. J Dent Res 1989;68:1786-1789.

-Summney DL, Jordan HV: Characterization of bacteria isolated from human root surface caries. J Dent Res 1974;53:343-351.

-Syed SA, Loesche WJ, Pape HL Jr, Grenier E: Predominant cultivable flora isolated from human root surface caries plaque. Infect Immun 1975;11:727-731.

Tan HP, Lo EC, Dyson JE, Luo Y, Corbet EF: A randomized trial on root caries prevention in elders. J Dent Res 2010;89:1086-1090.

Twetman S: Antimicrobials in future caries control? A review with special reference to chlorhexidine treatment. Caries Res 2004; 38:223-229.

Van der Weijden F, Dell'Acqua F, Slot DE: Alveolar bone dimensional changes of post-extraction sockets in humans: a systematic review. J Clin Periodontol 2009;36:1048-1058.

-Verhagen AP, de Vet HCW, de Bie RA, Kessels AGH, Boers M, Bouter LM, Knipschild PG: The Delphi List: a criteria list for quality assessment of randomized clinical trials for conducting systematic reviews developed by Delhi Consensus. J Clin Epidemiol 1998;51: 1235-1241.

Wallace MC, Retief DH, Bradley EL: The 48-month increment of root caries in an urban population of older adults participating in a preventive dental program. J Public Health Dent 1993;53:133-137.

-Wicht MJ, Haak R, Lummert D, Noack MJ: Treatment of root caries lesions with chlorhexidine-containing varnishes and dentin sealants. Am J Dent 2003;16(Spec No):25A-30A.

Zhang Q, Mulder J, Truin GJ, van Palenstein Helderman WH: Effect of $40 \%$ chlorhexidine varnish on mutans streptococci counts in pits and fissures of permanent first molars. J Dent 2007;35:588-592.

Zhang Q, van Palenstein Helderman WH, van't Hof MA, Truin GJ: Chlorhexidine varnish for preventing dental caries in children, adolescents and young adults: a systematic review. Eur J Oral Sci 2006;114:449-455. 